\title{
Evaluation of immunomodulatory effects of lomefloxacin in mice
}

\author{
Arfa Majeed ${ }^{1}$, Aqeel Javeed ${ }^{\circledR 1 *}$, Muhammad Ovais Omer ${ }^{1}$, \\ Muhammad Hassan Mushtaq ${ }^{2}$, Adeel Sattar ${ }^{1}$ \\ ${ }^{1}$ Department of Pharmacology and Toxicology, University of Veterinary and \\ Animal Sciences, Lahore, Pakistan, ${ }^{2}$ Department of Epidemiology \& Public \\ Health, University of Veterinary and Animal Sciences, Lahore, Pakistan
}

\begin{abstract}
Lomefloxacin is a flouroquinolone antibiotic that is quite efficacious against many gram negative and gram positive pathogens. Lomefloxacin evince antibacterial effects by modifying DNA gyrase in gram negative pathogens and topoisomerase IV in gram positive pathogens. This study is designed to assess the immunomodulatory effects of lomefloxacin in male albino mice. Three doses of lomefloxacin $12.5 \mathrm{mg} / \mathrm{kg}, 25 \mathrm{mg} / \mathrm{kg}$ and $50 \mathrm{mg} / \mathrm{kg}$ were used and delayed type hypersensitivity assay, cyclophosphamide induced neutropenic assay, carbon clearance assay, heamagglutination assay and mice lethality test were performed to evaluate the effects of lomefloxacin on immune system of mice. DTH assay has depicted the significant immunosuppressant potential of lomefloxacin at $25 \mathrm{mg} / \mathrm{kg}$ and $50 \mathrm{mg} / \mathrm{kg}$ dose. Total leukocyte count have exhibited highly significant reduction $(\mathrm{P}<0.001)$ in leukocyte count after cyclophosphamide administration. Differential leukocyte count has shown significant $(\mathrm{P}<0.01)$ reduction in lymphocyte count, whereas, highly significant $(\mathrm{P}<0.001)$ increase in monocyte count and significant $(\mathrm{P}<0.05)$ increase neutrophil count has been observed. In carbon clearance assay, highly significant $(\mathrm{P}<0.01)$ increase in phagocytic index has been noted at $12.5 \mathrm{mg} /$ $\mathrm{kg}$ and $25 \mathrm{mg} / \mathrm{kg}$ doses. Humoral immune system responses are suppressed in dose dependent manner by both heamagglutination assay $(\mathrm{P}<0.001)$ and mice lethality assay $(\mathrm{P}<0.001)$. Results clearly depict that lomefloxacin possess quite significant immunomodulatory potential.
\end{abstract}

Keywords: Cell-mediated. Humoral. Immunomodulatory. Immune response. Lomefloxacin.

\section{INTRODUCTION}

Lomefloxacin is a fluoroquinolone antibiotic (Hidaka, Kobayashi et al., 2015). Lomefloxacin exhibits such unique properties that favor treatment of a number of infective diseases and forge them eminently effectual against both gram positive pathogens and gram negative pathogens (Bradley, Jackson, 2011). Lomefloxacin is effective in infections caused by various pathogens including Mycobacterium,

*Correspondence: A. Javeed. Department of Pharmacology \& Toxicology. University of Veterinary and Animal Sciences. 54000, Lahore, Pakistan. Tel. 0092-42-99211374, 99211449, Ext. 230. Email: aqeel.javeed@uvas. edu.pk
Chlamydia and Mycoplasma and is also efficacious in treating community-acquired pneumonia (Walker, 1999). Lomefloxacin evince antibacterial effects by modifying DNA gyrase in gram negative pathogens and topoisomerase IV is the primary target in gram positive organisms (Bearden, Danziger, 2001). It is the fourth most prescribed medicine around the globe (Oliveira, Maniero, Guimaraes, 2015). The prolonged half-life and good tissue penetrating potential encompassing its activity in the cerebrospinal fluid (CSF) and its distinctive aptitude against lung infections, abdominal and dermal infections signifies that in upcoming era adjustments and refinements in the drug might give us a useful medicinal drug for clinical serviceability (Andriole, 1999). 
Lomefloxacin has a bicyclic aromatic core with a Fluorine substitution at $8^{\text {th }}$ carbon owing to its better oral absorption (Chu, Fernandes, 1989). Fluoro- substitution in aromatic core beneficial in escalating the drug's penetration into the microbial cell and thus in return augment the activity of the drug. This substitution lead to the development of new generation of fluoroquinolone drugs (Kłosińska-Szmurło et al., 2014). A research study suggests that lomefloxacin when conjugated with copper iodide or copper thiocyanate become much more durable compounds with enhanced cytotoxicity properties. Lomefloxacin-copper complex when tested on three different tumor cell lines exhibited much better anti-tumor activity as compared to parent compound and cisplatin an anti-tumor drug (Komarnicka et al., 2016).

Fluoroquinolones are known to exert modulatory effects on immune response when given to treat bacterial diseases (Badari et al., 2015). In various incidents it was observed that beside inhibiting bacterial cell growth or multiplication antibiotics also have beneficial immunomodulatory effects in host against localized or systemic infections (Badari, El-Fatah, Kamel, 2014). Lomefloxacin similar to other fluoroquinolones boost in-vitro production of interleukin-2 but impedes the production of interleukin-1 and TNF- $\alpha$, they also augment the production of CSF. By utilizing these pathways lomefloxacin act upon cellular and humoral immune processes by modifying cytokine levels and responses induced by them (Dalhoff, Shalit, 2003). In the current consideration, immunomodulatory effect on lomefloxacin in mice is to be evaluated. In this proposal we shall assess whether lomefloxacin potentiate or suppress immune system in mice.

\section{MATERIAL AND METHODS}

\section{Experimental animals}

Male albino mice 5-6 weeks old with weight between 25-30 grams were purchased from Department of Theriogenology, UVAS, Lahore. Mice were placed in clean environment with suitable temperature and humidity maintained. Standard pellet diet and water was given to all mice on regular basis during the research.

\section{Chemicals}

Lomefloxacin was purchased from Hubei Ocean Biotech, China via Scottman Pharmaceutical,
Islamabad. Acetone, Dinitrochlorobenzene (DNCB), Phosphate buffer saline (PBS), Distil water for injection obtained from the Department of Pharmacology and Toxicology, UVAS, Lahore. Cyclophosphamide powder for injection was obtained from Clinix Pharmacy, Lahore.

\section{Antigens}

2\% DNCB suspension was used in delayed type hypersensitivity assay as antigen. Sheep RBC's obtained from sheep available at animal house of UVAS, Lahore, and used as antigen in heamagglutination assay. Pasteurella multocida strains were taken by University Diagnostic lab, UVAS, Lahore and were used in mice lethality test.

\section{EXPERIMENTAL DESIGN}

The objective of the study was to evaluate the effect of lomefloxacin on immune system. Response of cell mediated immunity to lomefloxacin was determined by three tests, which were delayed type hypersensitivity test, cyclophosphamide induced neutropenia and carbon clearance test, whereas, humoral immunity response was examined by two assays, one was heamagglutination assay and the other was mice lethality test.

Mice were used as test animal and these were divided into 5 groups with 5 mice in each group. These groups were named as Group 1 Group 2, Group 3, Group 4 and Group 5. Group 1 was considered as negative control group and was administered water via injection. Cyclophosphamide was administered to Group 2 and named as positive control group. Lomefloxacin was administered intraperitoneally to Group 3, Group 4, and Group 5 at dose of $12.5 \mathrm{mg} / \mathrm{kg}, 25 \mathrm{mg} / \mathrm{kg}$ and $50 \mathrm{mg} /$ $\mathrm{kg}$, respectively. All ethical guidelines as indicated in institutional protocols were followed.

\section{Delayed type hypersensitivity assay}

In this test, two sides of the mice were used for application of DNCB solution. On $2^{\text {nd }}$ day of the trial, hairs from left side of the mice were removed by surgical scissors and sensitizing dose i.e. $0.1 \mathrm{~mL}$ DNCB solution was applied. On $8^{\text {th }}$ day of the trial, $0.2 \mathrm{~mL}$ DNCB solution was applied to right side of the mice. Change in skin thickness was measured after 24, 48 and 72 hours using vernier caliper (Sajid et al., 2007). 


\section{Cyclophosphamide induced neutropenic assay}

In this assay 4 groups of mice were used. Group 2, 3 and 4 received three different doses of lomefloxacin and Group 1 received water for injection. On $10^{\text {th }}$ day of trial, blood was withdrawn from the mice and collected in heparinized vacutainer tubes. (Total leukocyte count) TLC and (Differential leukocyte count) DLC were performed on the blood samples. Cyclophosphamide at the dose of $200 \mathrm{mg} / \mathrm{kg}$ was injected to all mice subcutaneously. On $13^{\text {th }}$ day of the trial, blood was again collected by puncturing the heart of the mice and TLC and DLC was performed (Thomas et al., 2007).

\section{Carbon clearance test}

Lomefloxacin were administered to the Group 2, 3 and 4, whereas control groups received $1 \%$ carboxymethyl cellulose (CMC) orally. On the $7^{\text {th }}$ day of trial, all animals were injected with indian ink dispersion intravenously. $50 \mu \mathrm{L}$ of blood was withdrawn in EDTA solution at time interval of 0 and 15 mins. In order to lyse erythrocytes, blood samples were added to $2 \mathrm{~mL}$ of $0.1 \%$ sodium carbonate. Optical density was checked at $660 \mathrm{~nm}$ in a spectrophotometer (Bharani et al., 2010).

\section{Heamagglutination assay}

Lomefloxacin was administered to treatment groups for 28 days. Mice were injected with $0.5 \times 10^{9}$ sheep red blood cells (SRBCs) intraperitonealy on $14^{\text {th }}$ day and on $21^{\text {st }}$ day. On the $28^{\text {th }}$ day blood samples were collected in eppendroff tubes by puncturing the heart of mice. 96 well round bottom plates were used to perform the antibodies titre. $50 \mu \mathrm{L}$ of PBS was added in each well and $50 \mu \mathrm{L}$ of serum was added to each well than $50 \mu \mathrm{L}$ of $1 \%$ SRBCs were added in each well. The plates were left intact for 2 hours and results were noted (Fulzele et al., 2003).

\section{Mice lethality test}

Lomefloxacin was given intraperitoneally to Group 2,3 and 4 for 21 days. On $7^{\text {th }}$ and $17^{\text {th }}$ day, mice were immunized by hemorrhagic septicemic vaccine. On $21^{\text {st }}$ day, mice were given $0.2 \mathrm{~mL}$ of pasteurella multocida culture subcutaneously. Animals were observed for 72 hours and mortality ratio was evaluated (Sudha et al., 2010).

\section{Statistical analysis}

Collected data were analyzed by statistic package for social sciences (SPSS). ANOVA was applied. Difference was considered significant at $\mathrm{P}<0.05$.

\section{RESULTS AND DISCUSSION}

\section{Delayed type hypersensitivity assay}

The impact of lomefloxacin on cellular immune system was evaluated delayed type hypersensitivity assay in which DNCB was used as antigen to provoke immune response in mice (Sajid et al., 2007). DNCB when applied on epidermis gets absorbed and attains access to lymphatic system and it abet several cellmediated immune responses including pustules, irritation, increase in skin thickness and inflammation (Gaspari, Katz, Martin, 2016). Results indicate highly significant $\left(\mathrm{P}<0.01^{* *}\right)$ suppression of skin thickness after 24 hours of challenging dose (Figure 1). After 48 hours, lomefloxacin $(12.5 \mathrm{mg} / \mathrm{kg})$ exhibited increase $\left(\mathrm{P}<0.001^{* * *}\right)$ in skin thickness, whereas, lomefloxacin at doses $25 \mathrm{mg} / \mathrm{kg}$ and $50 \mathrm{mg} / \mathrm{kg}$ showed very highly significant $(\mathrm{P}<0.001 * * *)$ suppression of skin thickness. After 72 hours lomefloxacin at $12.5 \mathrm{mg} / \mathrm{kg}$ exhibited very highly significant $\left(\mathrm{P}<0.001^{* * *}\right)$ suppression of skin thickness, whereas, lomefloxacin at $25 \mathrm{mg} / \mathrm{kg}$ and $50 \mathrm{mg} / \mathrm{kg}$ exhibited high significantly $\left(\mathrm{P}<0.001^{* * *}\right.$, $\mathrm{P}<0.05^{*}$ ) increase in skin thickness.

\section{Cyclophosphamide induced neutropenic assay}

Cyclophosphamide induced neutropenia assay was designed to assess the effects of lomefloxacin on mice with leukopenia. Cyclophosphamide besides being antitumor drug also possess immunosuppressant properties (Zuluaga et al., 2006). In current study, TLC and DLC before and after subcutaneous administration of cyclophosphamide were evaluated. TLC results depicted very highly significant $\left(\mathrm{P}<0.001^{* * *}\right)$ decrease in leukocyte count in lomefloxacin $12.5 \mathrm{mg} / \mathrm{kg}$ group and significant $\left(\mathrm{P}<0.05^{*}\right)$ decrease in leukocyte count in 25 $\mathrm{mg} / \mathrm{kg}$ and $50 \mathrm{mg} / \mathrm{kg}$ group on $10^{\text {th }}$ day of the trial. Very highly significant $(\mathrm{P}<0.001 * * *)$ reduction in leukocyte count was observed in all the three lomefloxacin treated groups on $13^{\text {th }}$ day of the trial [Figure 2(A)]. DLC was performed to assess effects of lomefloxacin on lymphocytes, monocytes and neutrophils. Highly 


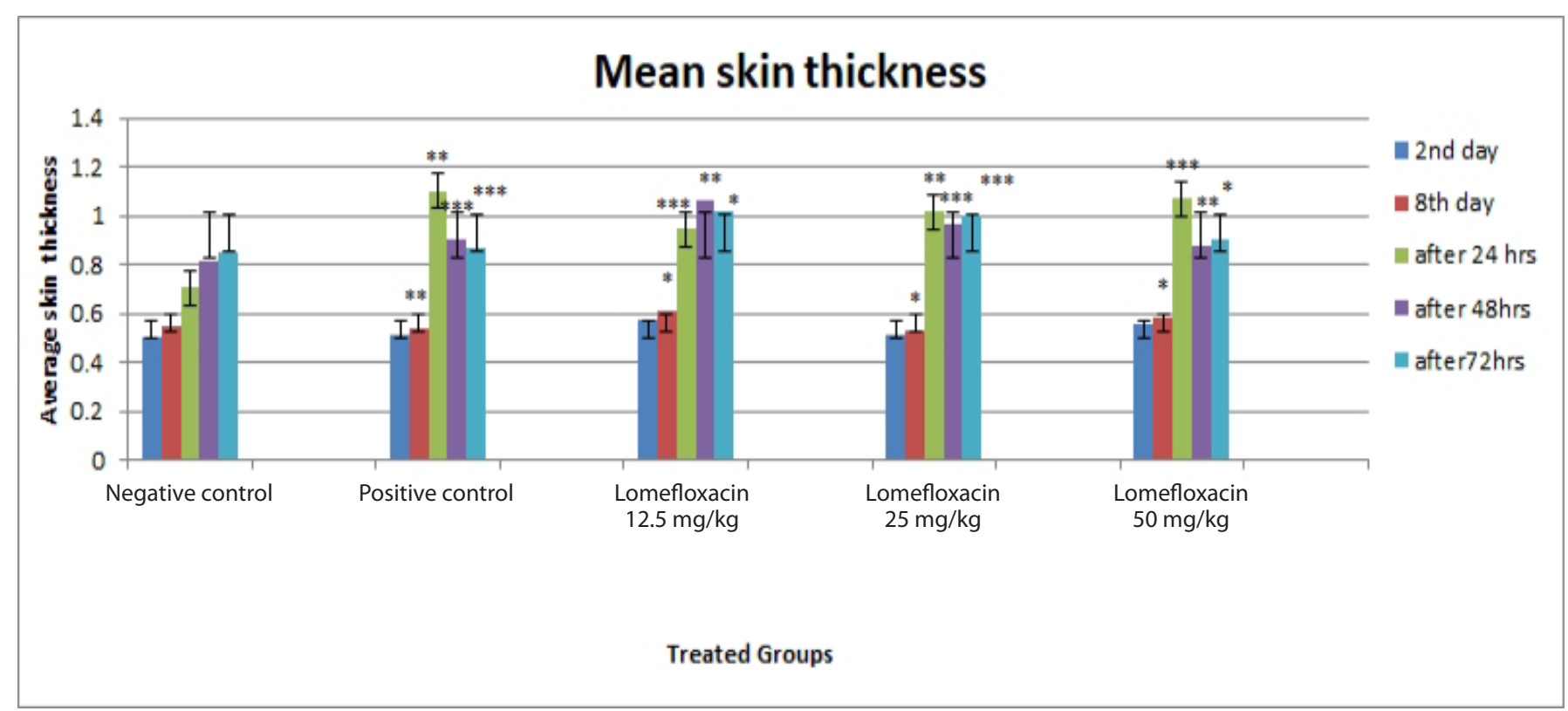

FIGURE 1 - Mean skin thickness variation among treatment groups after 24, 48 and 72 hours.

significant $\left(\mathrm{P}<0.01^{* *}\right)$ reduction in lymphocyte count was observed at dose $12.5 \mathrm{mg} / \mathrm{kg}$ and $50 \mathrm{mg} /$ $\mathrm{kg}$ and at $25 \mathrm{mg} / \mathrm{kg}$ significant $\left(\mathrm{P}<0.05^{*}\right)$ decrease in lymphocyte count was reported after cyclophophamide injection [Figure 2(b)]. Cyclophosphamide suppress lymphocytes by inducing myeloid-derived suppressor cells (MDSC) (Gabrilovich, Nagaraj, 2009). MDSC are cells of immune system that are derived from myeloid origin but contrary to other cells of myeloid origin MDSC suppress immune responses instead of potentiating immune response (Diaz-Montero et al., 2009). Very highly significant $\left(\mathrm{P}<0.001^{* * *}\right)$ reduction in monocyte count was noticed at dose of $12.5 \mathrm{mg} /$ $\mathrm{kg}$ in contrast to dose $25 \mathrm{mg} / \mathrm{kg}$ and $50 \mathrm{mg} / \mathrm{kg}$, which resulted in highly significant $\left(\mathrm{P}<0.001^{* * *}, \mathrm{P}<0.05^{*}\right)$ increase in monocyte count [figure 2(C)]. Monocytes are usually short lived and undergo apoptotic cell death every 24 hours (Parihar, Eubank, Doseff, 2010). Increase in monocytes and neutrophils indicate that lomefloxacin may have potentiating effect on myeloid progenitor cells similar to moxifloxacin which suppress immune responses but induce monocytes and neutrophil production by acting on myeloid progenitor cells (Shalit et al., 2001). Highly significant $\left(\mathrm{P}<0.01^{* *}\right)$ augmentation in neutrophil number was observed after administration of cyclophosphamide in $12.5 \mathrm{mg}$ / $\mathrm{kg}$ and $50 \mathrm{mg} / \mathrm{kg}$ treatment groups and significant $\left(\mathrm{P}<0.05^{*}\right)$ augmentation was noticed in case of 25 $\mathrm{mg} / \mathrm{kg}$ treatment group [Figure 2(D)]. These results indicate that increase in monocyte count and neutrophil count owe to the unique property of flouroquinolones. Flouroquinolones suppress the immune response but enhance the monocytes and neutrophil count by acting on myeloid progenitor cells. 


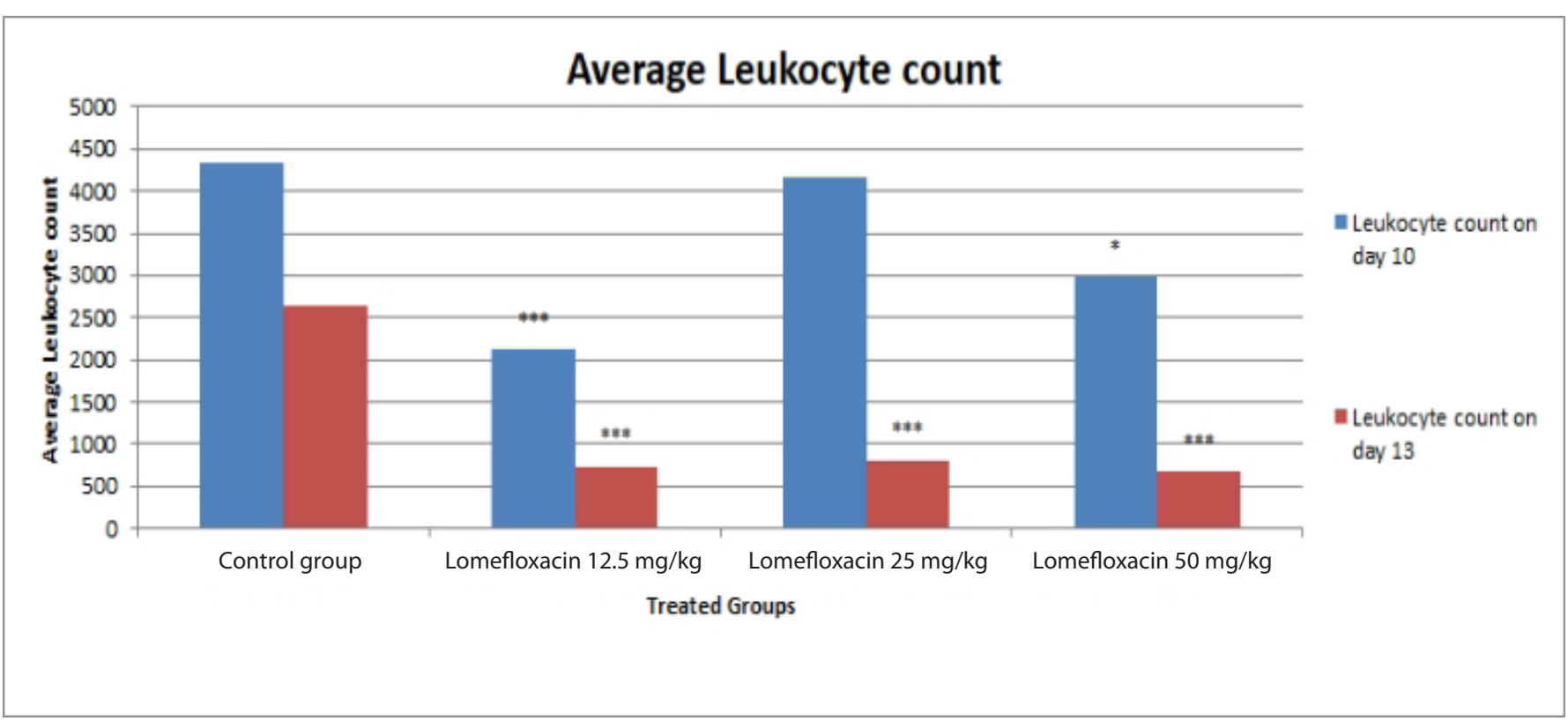

FIGURE 2 (A) - Leukocytes count befor e and after cyclophophamide administration.

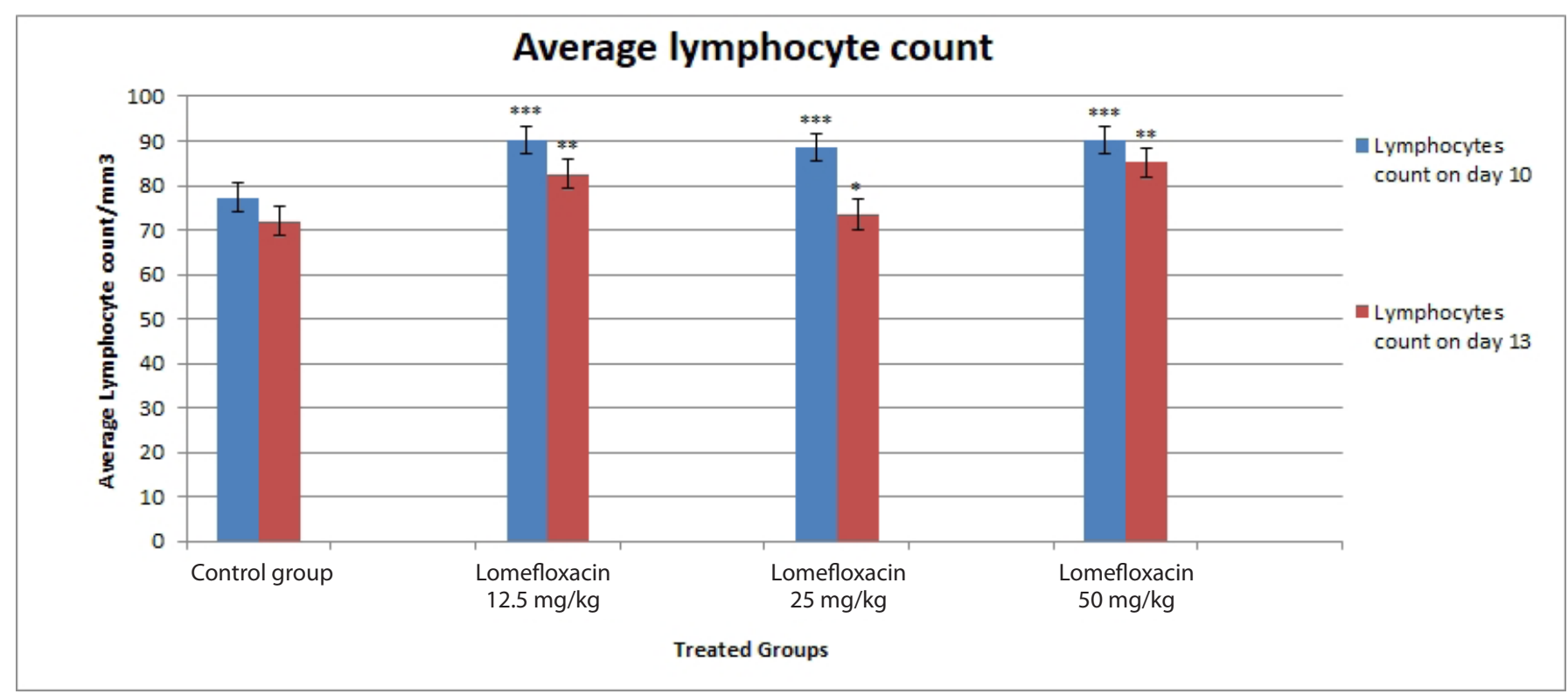

FIGURE 2 (B) - Lymphocytes count before and after cyclophophamide administration. 


\section{monocyte count}

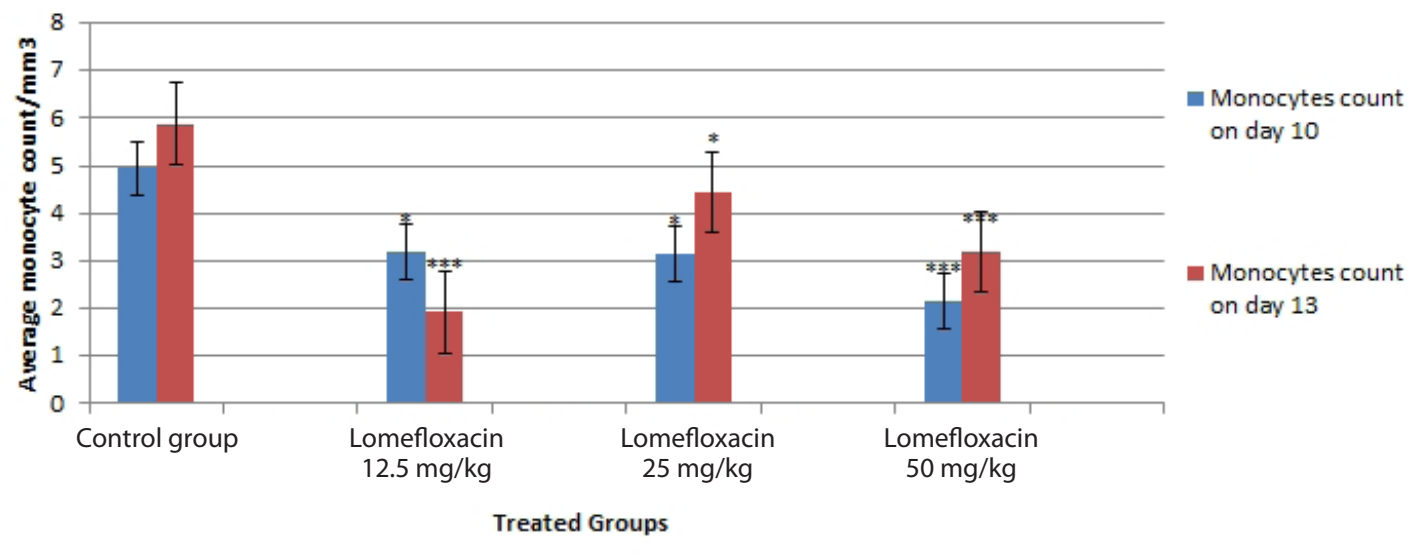

FIGURE 2 (C) - Monocytes count before and after cyclophophamide administration.

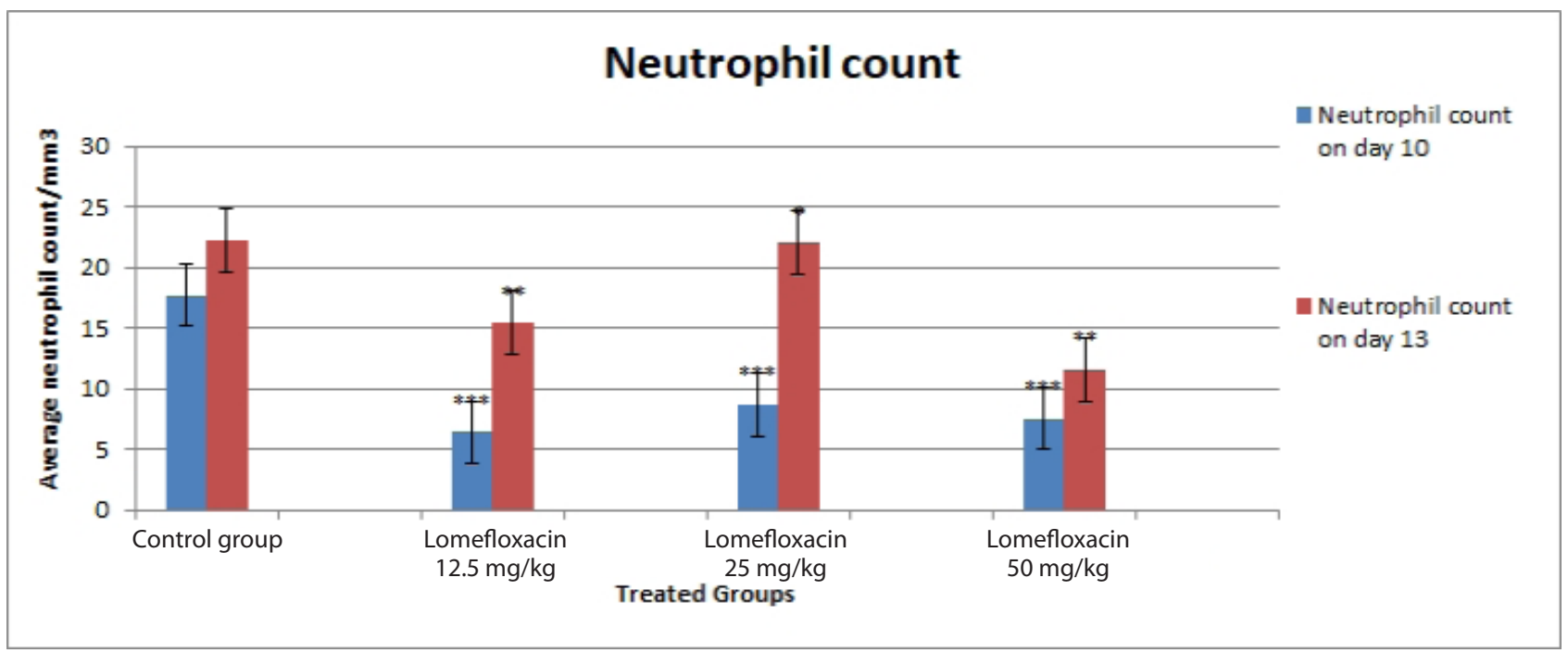

FIGURE 2 (D) - Neutrophils count before and after cyclophophamide administration.

\section{Heamagglutination assay}

This assay was done to appraise the effect of lomefloxacin on reticulo endothilial system (RES) (Hajra, Mehta, Pamndey, 2012). RES consist of phagocytic cells primarily monocytes and macrophages which mostly assemble in spleen or lymphatic system (Govinda, Asdaq, 2011). When ink was administered intravenously in mice, macrophages engulfed the carbon particulates of Indian ink and percentage of removal of carbon particles from the blood is known as phagocytic index (George et al., 2014). Control group depicted immunosuppressant effects, whereas, lomefloxacin treated groups showed highly significant
$\left(\mathrm{P}<0.01^{* *}\right)$ immunostimulatory effects (Figure 3$)$. At dose $12.5 \mathrm{mg} / \mathrm{kg}$ and $25 \mathrm{mg} / \mathrm{kg}$, phagocytic index was greater than $50 \mathrm{mg} / \mathrm{kg}$ indicating that injected carbon particles were immediately engulfed by macrophages in lomefloxacin treated groups compared to control group. Immunosuppressant effect in control group is due to slow clearance of CMC from blood stream, whereas, lomefloxacin, an antibiotic that also has immunosuppressant effects but a unique feature of stimulating myeloid progenitor cells resulted in enhanced production of macrophages which resulted in faster clearance of carbon particles after being injected with Indian ink (Singh, Yadav, 2014). 


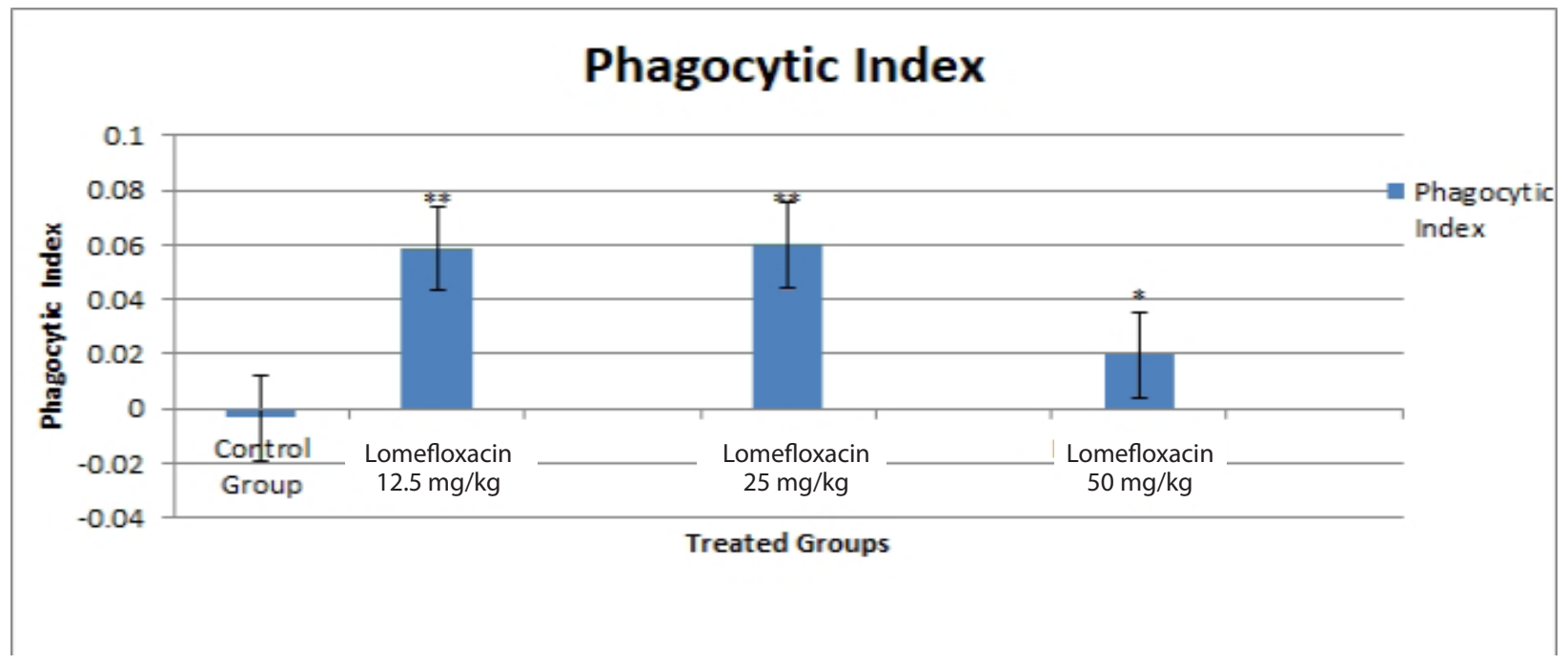

FIGURE 3 - Phagocytic index of treatment groups.

\section{eamagglutination assay}

Humoral immune response is acquired by generation of antibodies against the specific antigen (Vos et al., 2000). Antibodies bind with the specific antigen and neutralize it or form meshwork that is engulfed by phagocytic cells (Dashputre, Naikwade, 2010). Binding of antibodies with sheep RBCs lead to the formation of agglutination in the 96 well round bottom plate which was reported as positive result, whereas, in cases when no antibodies were produced, sheep RBCS settled down leading to bead formation such cases were reported as negative result (Fulzele et al., 2003). Negative control group resulted paramount generation of antigen antibody complexes, whereas, positive control group exhibited least agglutination. Lomefloxacin treated groups resulted in very highly significant $\left(\mathrm{P}<0.001^{* * *}\right)$ dose associated decrement of antibodies formations (Figure $4)$. These results are a clear indication that lomefloxacin has immunosuppressant effects.

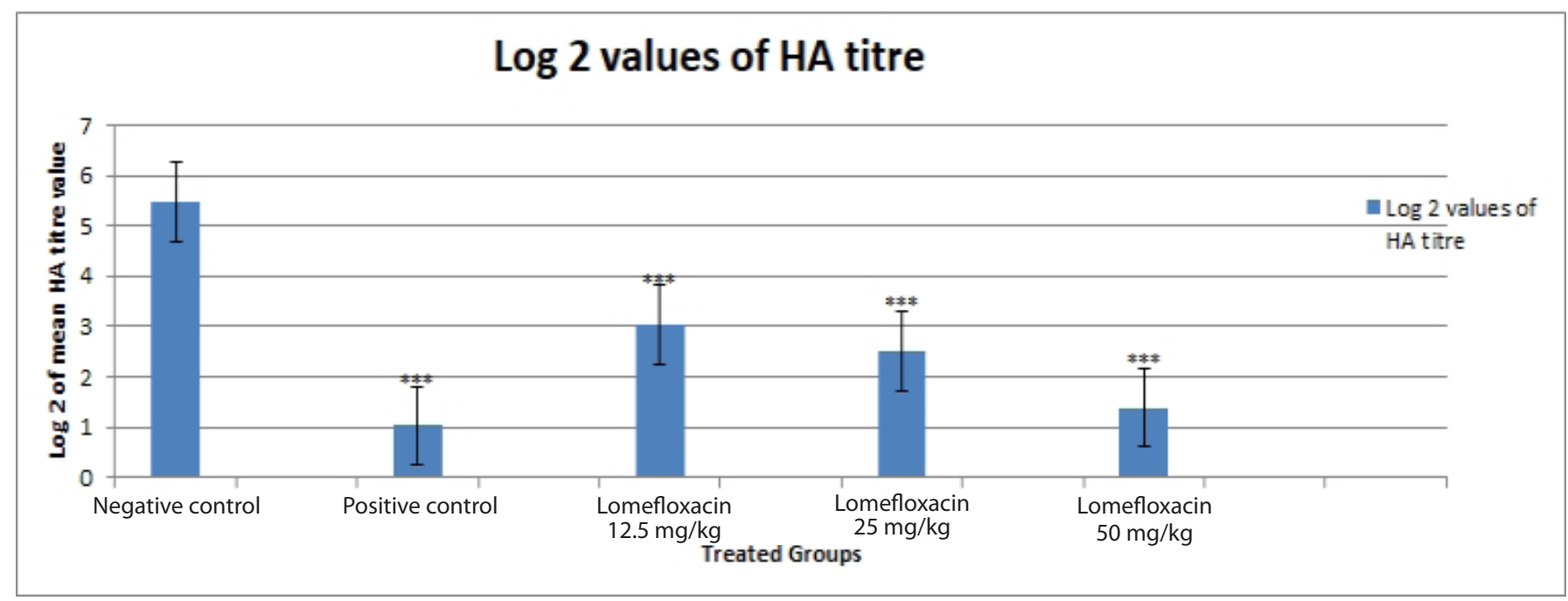

FIGURE 4 - Log 2 of mean HA titre value. 


\section{Mice lethality test}

One of the most widely used serological test is mice lethality test in which mice are challenged with Pasteurella multocida toxin after being vaccinated with HS-vaccine (Finco-Kent et al., 2001). PMtoxin induces a protein which enhance many cellular transduction pathways by stimulating $G$ proteins leading to mutogenesis (Orth, Aktories, 2010). Mortality rate indicates the presence or absence of antibodies in mice serum against the toxin (Johnson et al., 2006). Mortality rate increased with increasing dose of lomefloxacin indicating immunosuppressant properties of drug. $20 \%$ mice died in negative control group, $80 \%$ died in positive control group, whereas, dose dependent mortality was observed in lomefloxacin treated groups that is $60 \%, 80 \%$ and $100 \%$ mice died at dose $12.5 \mathrm{mg} / \mathrm{kg}, 25 \mathrm{mg} / \mathrm{kg}$ and 50 $\mathrm{mg} / \mathrm{kg}$, respectively (Figure 5 ).

The results suggest that lomefloxacin possess immunomodulatory effects. Lomefloxacin supresses the humoral immune system in dose dependent manner while it exhibits suppressive effects on cell mediated immune system at specific doses. Lomefloxacin beside suppressive effects on immune system also has some modulatory effects on myeloid cells and myeloid derived suppressor cells which may need further research in order to develop new medicinal use of lomefloxacin beside its antibacterial effects. Lomefloxacin may be useful in medicinal conditions like autoimmune disease treatments, organ transplant surgeries or tumor because of its immunosuppressive potential.

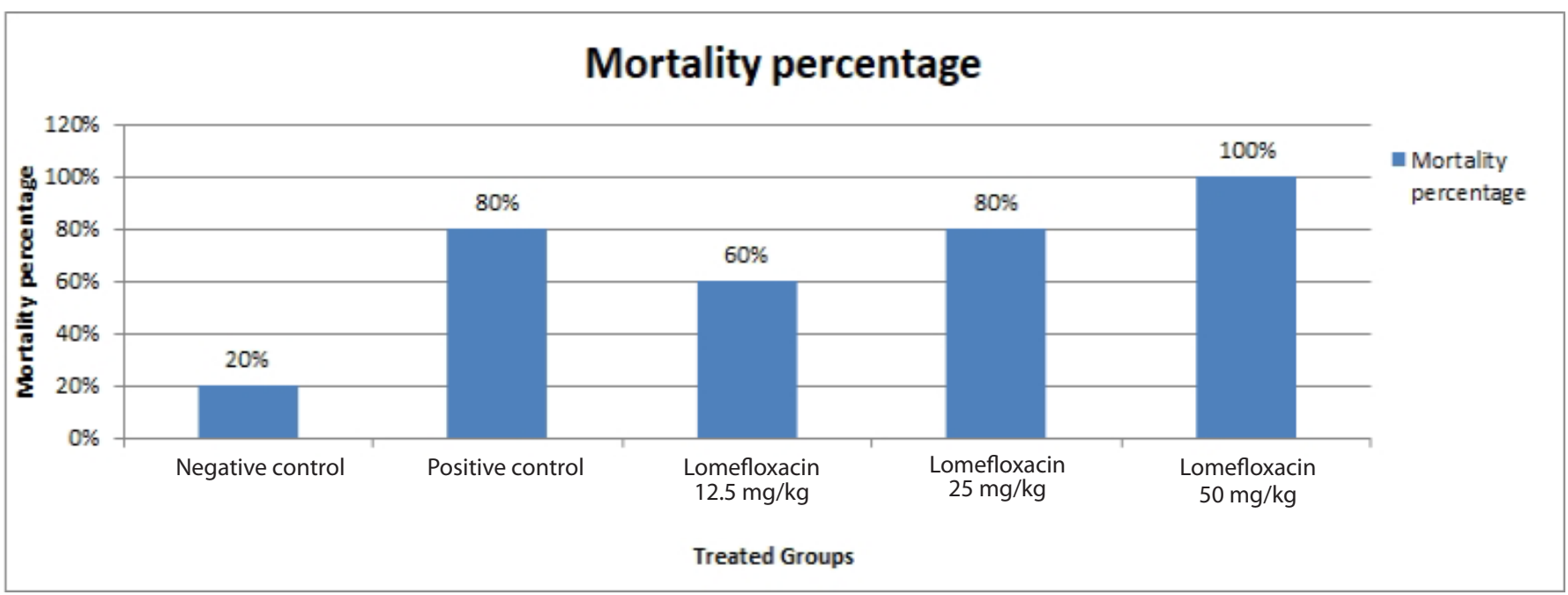

FIGURE 5 - Comparison of percentage mortality in control group and lomefloxacin treated groups.

\section{CONCLUSION}

This study clearly depicts that lomefloxacin possess potential to affect both innate and adaptive immune system. The immunomodulatory effects of this drug could be helpful in treatment of patients suffering from autoimmune disease and could also be useful in cancer treatment. Further research on cocrystalization of this drug with other salts and deep analyses of its effects on immune system in cancer patients and immunocompromised patients could lead to better understanding and better usage of the drug.

\section{ACKNOWLEDGMENT}

This research work was conducted in Department of Pharmacology and Toxicology, UVAS, Lahore and financial support for completion of this research project was also provided by Department of Pharmacology and Toxicology, UVAS, Lahore.

\section{CONFLICT OF INTEREST}

The authors have no conflict of interest. 


\section{REFERENCES}

Andriole VT. The future of the quinolones. Drugs. $1999 ; 58(2): 1-5$.

Badari MS, El-Fatah SGA, Kamel SI. Immunomodulatory action of levofloxacin on cytokine production in adults with community-acquired pneumonia. Med J Cairo. 2014;82(2):127-132.

Badari MS, Elgendy SG, Mohamed AS, Hassan AT. Immunomodulatory effects of levofloxacin on patients with pneumonia in Assiut University Hospitals. Egypt J Immunol. 2015;22(1):85-91.

Bearden DT, Danziger LH. Mechanism of action of and resistance to quinolones. Pharmacother J Hum Pharmacol Drug Ther. 2001;21(10):2-3.

Bharani SER, Asad M, Dhamanigi SS, Chandrakala GK. Immunomodulatory activity of methanolic extract of Morusalba Linn.(mulberry) leaves. Pak J Pharm Sci. 2010;23(1):63-68.

Bradley JS, Jackson MA, Diseases CoI. The use of systemic and topical fluoroquinolones. Am Acad Pediatrics. 2011;128(4):1034-1045.

Chu D, Fernandes PB. Structure-activity relationships of the fluoroquinolones. Antimicrob Agents Chemother. 1989;33(2):131-135.

Dalhoff A, Shalit I. Immunomodulatory effects of quinolones. Lancet Infect Dis. 2003;3(6):359-371.

Dashputre N, Naikwade N. Immunomodulatory activity of Abutilon indicum linn on albino mice. Int J Pharm Sci Res. 2010;1(3):178-184.

Diaz-Montero CM, Salem ML, Nishimura MI, Garrett-Mayer E, Cole DJ, Montero AJ. Increased circulating myeloidderived suppressor cells correlate with clinical cancer stage, metastatic tumor burden, and doxorubicin-cyclophosphamide chemotherapy. Cancer Immunol Immunother. 2009;58(1): 49-59.

Finco-Kent D, Galvin J, Suiter B, Huether M. Pasteurella multocida toxin type D serological assay as an alternative to the toxin neutralisation lethality test in mice. Biologicals. 2001;29(1):7-10.

Fulzele S, Satturwar P, Joshi S, Dorle A. Study of the immunomodulatory activity of Haridradi ghrita in rats. Indian J Pharmacol. 2003;35(1):51-54.
Gabrilovich DI, Nagaraj S. Myeloid-derived suppressor cells as regulators of the immune system. Nat Rev Immunol. 2009;9(3):162-174.

Gaspari AA, Katz SI, Martin SF. Contact hypersensitivity. Curr Protocols Immunol. 2016;113(1):42 1-427.

George A, Chinnappan S, Choudhary Y, Bommu P, Sridhar M. Immunomodulatory activity of an aqueous extract of Polygonum minus Huds on Swiss albino mice using carbon clearance assay. Asian Pac J Trop Dis. 2014;4(5):398-400.

Govinda H, Asdaq S. Immunomodulatory potential of methanol extract of Aegle marmelos in animals. Indian J Pharm Sci. 2011;73(2):235-240.

Hajra S, Mehta A, Pandey P. Immunostimulating activity of methanolic extract of Swietenia mahagoni seeds. Int J Pharm Pharm Sci. 2012;4(1):442-445.

Hidaka S, Kobayashi M, Ando K, Fujii Y. Efficacy and safety of lomefloxacin on bacterial extraocular disease in the horse. J Vet Med Sci. 2015;77(7):829-835.

Johnson JR, Clermont O, Menard M, Kuskowski MA, Picard B, Denamur E. Experimental mouse lethality of Escherichia coli isolates, in relation to accessory traits, phylogenetic group, and ecological source. J Infect Dis. 2006;194(8): 1141-1150.

Kłosińska-Szmurło E, Grudzień M, Betlejewska-Kielak K, Pluciński FA, Biernacka J, Mazurek AP. Physico-chemical properties of lomefloxacin, levofloxacin and moxifloxacin relevant to Biopharmaceutics Classification System. Acta Chim Slov. 2014;61(4):827-834.

Komarnicka UK, Starosta R, Kyzioł A, Płotek M, Puchalska M, Jeżowska-Bojczuk M. New copper (I) complexes bearing lomefloxacin motif: Spectroscopic properties, in vitro cytotoxicity and interactions with DNA and human serum albumin. J Inorg Biochem. 2016;165(1):25-35.

Oliveira A, Maniero MG, Guimaraes JR. Lomefloxacin degradation: antimicrobial activity, toxicity and byproducts. J Adv Oxid Technol. 2015;18(2):211-220.

Orth JH, Aktories K. Pasteurella multocida toxin activates various heterotrimeric $\mathrm{G}$ proteins by deamidation. Toxins. 2010;2(2):205-214.

Parihar A, Eubank TD, Doseff AI. Monocytes and macrophages regulate immunity through dynamic networks of survival and cell death. J Innate Immun. 2010;2(3): 204-215. 
Sajid MS, Iqbal Z, Muhammad G, Sandhu MA, Khan MN, Saqib M, et al. Effect of ivermectin on the cellular and humoral immune responses of rabbits. Life Sci. 2007;80(21): 1966-1970.

Shalit I, Kletter Y, Halperin D, Waldman D, Vasserman E, Nagler A, et al. Immunomodulatory effects of moxifloxacin in comparison to ciprofloxacin and G-CSF in a murine model of cyclophosphamide-induced leukopenia. Eur J Haematol. 2001;66(5):287-296.

Singh S, Yadav AK. Evaluation of immunomodulatory activity of Grewia asiatica in laboratory animals. J Chem Pharm Res. 2014;6(7):2820-2826.

Sudha P, Asdaq SMB, Dhamingi SS, Chandrakala GK. Immunomodulatory activity of methanolic leaf extract of moringa oleifera in animals. Indian J Physiol Pharmacol. 2010;54(2):133-140.
Thomas L, Asad M, Hrishikeshavan HJ, Chandrakala GK. Effect of centchroman on cellular and humoral immunity. Indian J Physiol Pharmacol. 2007;51(4):387-394.

Vos Q, Lees A, Wu ZQ, Snapper CM, Mond JJ. B-cell activation by T-cell-independent type 2 antigens as an integral part of the humoral immune response to pathogenic microorganisms. Immunol Rev. 2000;176(1):154-170.

Walker RC. The fluoroquinolones. Mayo Clin Proc. 1999;74(10):1030-1037.

Zuluaga AF, Salazar BE, Rodriguez CA, Zapata AX, Agudelo M, Vesga O. Neutropenia induced in outbred mice by a simplified low-dose cyclophosphamide regimen: characterization and applicability to diverse experimental models of infectious diseases. BMC Infect Dis. 2006;6(1): 55-78.

Received for publication on $13^{\text {th }}$ September 2018 Accepted for publication on $14^{\text {th }}$ November 2018 